\title{
PENGARUH KOMUNIKASI PEMASARAN, PENGALAMAN DAN KUALITAS JASA TERHADAP CITRA DAN KEPUASAN SERTA DAMPAKNYA PADA LOYALITAS WISATAWAN NUSANTARA (SURVEI TEMPAT REKREASI AIR TERJUN DI KABUPATEN BOGOR)
}

\author{
Wiwin Siswantini \\ Devi Ayuni \\ Andy Mulyana \\ Fakultas Ekonomi Universitas Terbuka \\ e-mail: wiwin@ut.ac.id
}

\begin{abstract}
The study aims to get an overview of marketing communications, experience and quality of services as the cause of image formation and satisfaction and its impact on loyalty of domestic tourists in the waterfall recreation area. The object of this research is waterfalls in Bogor, namely Curug Bidadari and Curug Nangka. The number of samples acceptable in this study is 50 respondents. This number is a critical sample size in the sample measurements required through SEM Partial Least Square (PLS). From the questionnaires distributed on both waterfalls, collected 114 complete questionnaires that can be processed. The data analyzed in this research using Partial Least Square (PLS) method and using Smart PLS tools. The results showed that marketing communications significantly related to the image. This shows that interesting communication will form a positive image and encourage tourists to visit. Compared with marketing communications, experience has more role in shaping the image of the place of recreation. Service quality is significantly related to image. Service quality has the most dominant effect on image over experience and communication. Service quality is significantly related to satisfaction. Service quality is not significantly related to loyalty. The image is significantly related to satisfaction. The image is not significantly related to loyalty. Although the image does not directly affect the loyalty, but the image has an indirect effect on loyalty through satisfaction. Satisfaction is significantly related to loyalty. Of all the variables that have influence on loyalty the biggest influence is the variable of respondent satisfaction, that is the promotion of this recreation place as a place of recreation.
\end{abstract}

Keywords: experience, image, loyalty, marketing communications, satisfaction, service quality.

\footnotetext{
ABSTRAK

Penelitian bertujuan untuk mendapatkan gambaran terkait komunikasi pemasaran, pengalaman dan kualitas jasa sebagai penyebab terbentuknya citra dan kepuasan serta dampaknya pada loyalitas wisatawan nusantara di tempat rekreasi air terjun. Objek penelitian ini adalah tempat wisata air terjun di Bogor, yaitu Curug Bidadari dan Curug Nangka. Jumlah sampel yang akseptabel dalam penelitian ini adalah 50 responden. Jumlah ini merupakan ukuran sampel kritis dalam pengukuran sampel yang diperlukan melalui SEM Partial Least Square (PLS). Dari kuesioner yang disebar pada kedua air terjun tersebut, terkumpul 114 kuesioner lengkap yang dapat diolah. Data yang dianalisis pada penelitian ini
} 
menggunakan metode Partial Least Square (PLS) dan menggunakan tools SmartPLS. Hasil penelitianmenunjukkan bahwa komunikasi pemasaran berhubungan signifikan terhadap citra. Hal ini menunjukkan bahwa komunikasi yang menarik akan membentuk citra yang positif dan mendorong wisatawan berkunjung. Dibandingkan dengan komunikasi pemasaran, pengalaman lebih berperan dalam membentuk citra tempat rekreasi. Kualitas jasa berhubungan signifikan terhadap citra. Kualitas jasa berpengaruh paling dominan terhadap citra dibandingkan pengalaman dan komunikasi. Kualitas jasa berhubungan signifikan terhadap kepuasan. Kualitas jasa tidak berhubungan signifikan terhadap loyalitas. Citra berhubungan signifikan terhadap kepuasan. Citra tidak berhubungan signifikan terhadap loyalitas. Walaupun secara langsung citra tidak berpengaruh terhadap loyalitas, tetapi citra berpengaruh tidak langsung terhadap loyalitas melalui kepuasan. Kepuasan berhubungan signifikan terhadap loyalitas. Dari semua variabel yang memiliki pengaruh terhadap loyalitas pengaruh terbesar adalah variabel kepuasan responden, yaitu promosi yang dilakukan tempat rekreasi ini sebagai suatu tempat rekreasi.

Kata kunci: citra, kepuasan, komunikasi pemasaran, kualitas jasa, loyalitas, pengalaman.

Peran sektor pariwisata semakin penting terhadap perkembangan perekonomian negaranegara ASEAN. Kemenparekraf (2014) menyatakan pertumbuhan sektor pariwisata ASEAN sepanjang periode 2005-2012 merupakan yang tertinggi di dunia, yaitu sebesar 8,3\% per tahun, jauh di atas rata-rata pertumbuhan global yang hanya 3,6\%. Bahkan pada tahun 2013, arus kunjungan wisatawan ke negara-negara ASEAN sudah mencapai 92,7 juta atau meningkat $12 \%$ dibandingkan tahun sebelumnya, sementara pertumbuhan global hanya $5 \%$. Kontribusi sektor pariwisata di Indonesia dalam beberapa tahun terakhir meningkat dari 10\% menjadi $17 \%$ dari total ekspor barang dan jasa dan posisinya sebagai penyumbang devisa meningkat dari peringkat 5 menjadi 4 dengan devisa sebesar USD 10 milyar.

Tabel 1. Ranking Devisa Pariwisata Tahun 2009-2013.

\begin{tabular}{|c|c|c|c|c|c|c|c|c|c|c|}
\hline \multirow[b]{2}{*}{ ent } & \multicolumn{2}{|l|}{20} & \multicolumn{2}{|l|}{$2=$} & \multicolumn{2}{|l|}{ xil } & \multicolumn{2}{|l|}{20} & \multicolumn{2}{|l|}{263} \\
\hline & bullonates: & $\begin{array}{l}\text { Exis } \\
\text { ust }\end{array}$ & kalonetu & 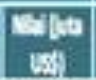 & varifosditas & $\frac{500}{50}$ & mill trovets: & 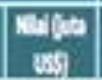 & 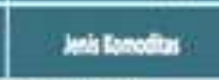 & (5) \\
\hline 1 & Nonat 6 pribon & 1904830 & Nongh s gestumi & 80356 & Neraispobos & $45, \pi n+8$ & Unpispabon & $36 \operatorname{sn} 01$ & Ninds pasbari & x653: \\
\hline 2 & ghein & Ben? & Staben & $\operatorname{tg} 6 x$ & Exiban & 27248 & Batan & $x: 5 \times 30$ & Batn & 2usut \\
\hline 3 & Nond itseregert & 1036.5 & 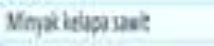 & 13,2885 & Mopal itasa iavt & $D 2513$ & Nopi ieves inet & 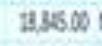 & Nonkitica unt? & $15 \mathrm{sP} .1$ \\
\hline 4 & Patiatan & 628en & Gresoly & 931657 & Eretobity & $\sin x$ & Goveloban & $233 \times 501$ & Pulveat & noset \\
\hline 5 & niam as & 5,37550 & nhiviut & 252215 & havist & 2554.40 & Whitat & 921208 & Greduren & 9, $\mathrm{ks}$ \\
\hline 6 & Gretolat & $4 x: 58$ & halas jos & 65311 & haiango & 1818 & hamjed & 730401 & painge & 7,540 \\
\hline 7 & Aalisti & $150 \mathrm{~s}$ & Ala lishi & 5,3250 & Astimi & $7 \% 4 x$ & Nat lest & 603180 & Aatien & 6,132, \\
\hline$t$ & Teist: & 36023 & Teval & $4 \pi \pi$ & Tries & 59436 & Thist & 5,25101 & Narats bitat & 5,643 \\
\hline 9 & Ieta das barsg thest & 3.05at & Tentus beterngtiets & 42473 & Vilisan obtar & 480212 & Heknatoban & 515560 & Teist & 5.3936 \\
\hline I) & Viarmodaten & 155073 & Nairatatn & 3,6216 & tanking & $4580 x$ & Letstantanter terti & $3 \sin 0$ & Kentate barag thintas & 38022 \\
\hline II & Goditan & 20532 & Altan ini & 3,35185 & Letalanberstrietra & 42140 & Granima & 3.65630 & Kovolate & 35425 \\
\hline 12 & Batan init & $2155 \mathrm{Al}$ & Gyolatan & 2800.69 & Gopdhyn & 32850 & Grodure: & 3337.20 & Batakinit & $350: 6$ \\
\hline
\end{tabular}

Sumber: Kemenparekraf, 2014

Menurut Kemenparekraf (2014), pada tahun 2014 pembangunan kepariwisataan di Indonesia dengan jumlah kunjungan wisatawan sebesar 9 juta Wisatawan dan tingkat pertumbuhan 
sebesar $8 \%$ (rangking ke-70 dari 140 negara di dunia). Pada 2019, jumlah kunjungan wisatawan adalah sebesar 20 juta dengan pertumbuhan sebesar 12\% per tahun (prediksi ranking ke-30 dari 140 negara). Kegiatan pariwisata dapat didefinisikan sebagai perjalanan satu atau sekelompok orang ke tempat yang bukan tempat tinggal atau tempat kerjanya dengan maksud untuk mencari kesenangan dan bukan dengan tujuan melaksanakan pekerjaan (Mill dan Morrison, 1985). Penyelenggara wisata haus menampilkan objek atau atraksi wisata yang menarik sehingga wisatawan nusantara (wisnu) dan wisatawan mancanegara (wisman) datang ke objek atau atraksi wisata tersebut.

Ada 3 unsur yang dibutuhkan untuk membentuk produk wisata tersebut, yaitu attraction of the destination including its image in the tourist's mind: facilities at the destination which include accommodation, catering, entertainment and recreation and accessibility of destination. Bila ketiga unsur tersebut dikembangkan sesuai dengan urutannya, yaitu semenjak seorang wisatawan meninggalkan kediamannya sampai di tempat tujuan dan kembali lagi ke rumah dimana biasanya ia tinggal, maka ada 8 unsur pokok yang membentuk produk tersebut sehingga merupakan suatu paket, yaitu jasa travel agen, jasa perusahaan pengangkutan, jasa pelayanan akomodasi, jasa retail agen, jasa transport lokal, objek wisata dan atraksi wisata, jasa toko souvenir dan handicraft serta jasa perusahaan pendukung. Kumpulan dari bermacam-macam perusahaan yang secara bersama menghasilkan barang-barang dan jasa-jasa yang dibutuhkan wisatawan pada khususnya dan traveler pada umumnya selama dalam perjalanannya disebut industri pariwisata (Yoeti, 1996).

Keinginan wisatawan untuk berkunjung perlu diiringi dengan kemudahan aksesibilitas, fasilitas yang ditawarkan dan ketersediaan sarana akomodasi. Aksesibilitas, fasilitas, dan akomodasi yang dikelola secara baik akan mampu menarik wisatawan dalam jumlah besar. Bogor merupakan daerah yang dapat ditempuh sekitar 1 jam dari kota besar seperti Jakarta menjadi alternatif bagi wisatawan yang ingin berwisata. Bogor memiliki beragam objek wisata dan sarana akomodasi. Keberagaman destinasi dan sarana akomodasi serta jajanan khas menjadikan Bogor semakin diminati wisatawan, baik wisnu maupun wisman. Tabel 2 merupakan data mengenai perkembangan kunjungan wisatawan ke Bogor tahun 2008-2012. Walaupun kunjungan wisnu maupun wisman ke Bogor menunjukkan tren meningkat dari tahun ke tahun, tetapi seperti daerah lain di Indonesia masih terdapat setidaknya 7 masalah yang menjadi hambatan pariwisata, yaitu sarana \& prasarana, SDM, komunikasi \& publisitas, kebijakan \& peraturan berlaku, teknologi informasi, dan kesiapan masyarakat (Nursastri, 2014).

Tabel 2. Pertumbuhan Kunjungan Wisatawan ke Bogor Tahun 2008-2012.

\begin{tabular}{crrrrr}
\hline Kategori & \multicolumn{5}{c}{ Tahun } \\
\cline { 2 - 6 } Wisatawan & \multicolumn{1}{c}{2008} & \multicolumn{1}{c}{2009} & \multicolumn{1}{c}{2010} & \multicolumn{1}{c}{2011} & \multicolumn{1}{c}{2012} \\
\hline Nusantara & 1.086 .374 & 1.190 .793 & 1.205 .628 & 1.309 .875 & 1.428 .957 \\
Mancangera & 102.737 & 102.055 & 104.076 & 106.137 & 110.219 \\
\hline Jumlah & 1.189 .111 & 1.292 .848 & 1.309 .704 & 1.416 .012 & 1.539 .176 \\
\hline
\end{tabular}

Sumber: Disbudpar Bogor, 2013

Air terjun merupakan salah satu tempat wisata alam yang cukup unik dan menarik di Bogor. Ada 8 air terjun yang dikenal masyarakat di Bogor, yaitu Curug Cigamea, Curug Ngumpet, Curug Pangeran, Curug Cilember, Curug Nangka, Curug Luhur, Curug Seribu dan Curug Nangka. Berdasarkan studi awal diketahui masih ada beberapa masalah yang jadi kendala seperti akses jalan dan transportasi yang kurang memadai, sarana dan prasarana wisata yang masih minim, serta 
kurangnya pemanfaatan teknologi informasi sebagai sarana promosi. Oleh karena itu, penelitian ini menjadikan wisata air terjun di Bogor sebagai tempat dan objek penelitian.

Berdasarkan latar belakang dapat dijelaskan bahwa penelitian ini perlu untuk memahami perilaku dan sikap wisatawan nusantara yang membentuk loyalitas melalui variabel kepuasan, citra, kualitas jasa, pengalaman dan komunikasi pemasaran. Menurut Witt dan Moutinho (1994), penelitian ini merupakan pengembangan model perilaku konsumen dengan prinsip teknik konstruksi. Model ini menganalisis perilaku repeat purchase dan brand loyalty dalam pemasaran pariwisata. Selanjutnya dapat dirumuskan permasalahan penelitian yaitu bagaimana pengaruh komunikasi pemasaran, pengalaman, dan kualitas jasa wisata terhadap citra tempat rekreasi air terjun di Bogor, bagaimana pengaruh citra dan kualitas jasa tempat rekreasi air terjun terhadap kepuasan dan loyalitas wisatawan nusantara, dan bagaimana pengaruh kepuasan terhadap loyalitas wisatawan nusantara. Sedangkan tujuan dari penelitian ini adalah untuk mengetahui pengaruh komunikasi pemasaran, pengalaman, dan kualitas jasa wisata terhadap citra tempat rekreasi air terjun di Bogor, pengaruh citra dan kualitas jasa tempat rekreasi air terjun terhadap kepuasan dan loyalitas wisatawan nusantara, pengaruh kepuasan terhadap loyalitas wisatawan nusantara.

Pariwisata merupakan salah satu bentuk produk yang digolongkan kedalam jasa dengan karakteristik yang dimiliki seperti bentuk jasa lainnya, yaitu tidak berwujud, tidak dapat dipisahpisahkan, berubah-ubah, dan tidak dapat disimpan.Bentuk jasa pariwisata yang tidak terlihat perlu diwujudkan agar wisatawan dapat memastikan pembelian jasa melalui informasi dan kepercayaan akan jasa yang diterimanya (Kotler et al., 2002). Kondisi alam kebersihan fasilitas wisata, atau keaneka-ragaman wujud jasa wisata menjadi tolok ukur kualitas jasa pariwisata.Industry pariwisata juga diistilahkan sebagai hospitality industries, karena produk yang dihasilkan merupakan produk hospitality, berupa barang, lingkungan, atau jasa/pelayanan yang inti produknya adalah pengalaman secara total atau pengalaman yang intangible (Lewis dan Chambers, 2000).

Menurut Lewis dan Chambers (2000) produk jasa yang disebut hospitality ini terdiri dari (1) tangible goods, barang fisik yang dapat dikendalikan oleh pihak manajemen secara langsung, kondisi dari fasilitas fisik seperti bangunan, furniture, kamar mandi, makanan, alat komunikasi, dan alat hiburan, (2) environment yaitu nuansa lingkungan yang masih dapat dikendalikan oleh pihak manajemen secara tidak langsung dan tidak semudah barang fisik, seperti segala sesuatu yang dirasakan wisatawan yang dapat terkait dengan barang fisik, misalnya dekorasi taman, tata letak tempat istirahat, pintu masuk, system antrian, pemilihan cat atau warna, (3) service, merupakan elemen sebagai atribut yang abstrak dan harus dikendalikan pihak manajemen karena paling dominan untuk menghadapi persaingan, dan sangat dipergaruhi oleh personal dari karyawan (keramahan, kecepatan, sikap, tanggungjawab, dapat dipercaya, tanggap), system yang digunakan, dan keputusan manajemen yang mengarah pada komitmen pimpinan untuk melakukan pelayanan yang ditawarkan, dan (4) experience, elemen ini penting karena merupakan hasil dari 3 elemen sebelumnya. Pengalaman akan diingat selama beberapa periode dan bersifat personal, diklasifikasikan sebagai kenangan yang intangible dan kejadiannya hanya sekali.

Pemasaran pariwisata atau tourism marketing menurut Wahab et al. (1997) merupakan suatu proses manajemen dari organisasi kepariwisataan nasional atau perusahaan industri pariwisata untuk menentukan wisatawan yang actual dan potensial, mengadakan komunikasi dengan wisatawan dalam menentukan serta mempengaruhi keinginan, kebutuhan, motivasi, kesukaan dan ketidaksukaan pada daerah-daerah local, regional, nasional, maupun internasional yang kemudian dirumuskan serta disesuaikan agar objek pariwisata dapat mencapai kepuasan optimal bagi wisatawan dan tujuan organisasi (Yoeti, 1996). Perilaku konsumen jasa wisata untuk selanjutnya 
disebut perilaku wisatawan, mempunyai peran yang sangat mendukung dalam pemasaran pariwisata. Pengertian perilaku konsumen oleh Loudon dan Bitta (1988) dinyatakan sebagai proses keputusan dan aktivitas fisik individu yang disertai dengan menilai, mengakui, menggunakan, atau membuang barang atau jasa. Pengertian yang sama diberikan Shiffman dan Kanuk (2000), yaitu merupakan perilaku yang ditunjukkan konsumen dalam pencarian, pembelian, penggunaan, penilaian, dan pembuangan produk barang, jasa dan ide. Sedangkan Morison (1996) menyatakan perilaku wisatawan merupakan cara wisatawan untuk memilih penggunaan dan bertindak setelah melakukan pembelian jasa wisata (post-purchase).

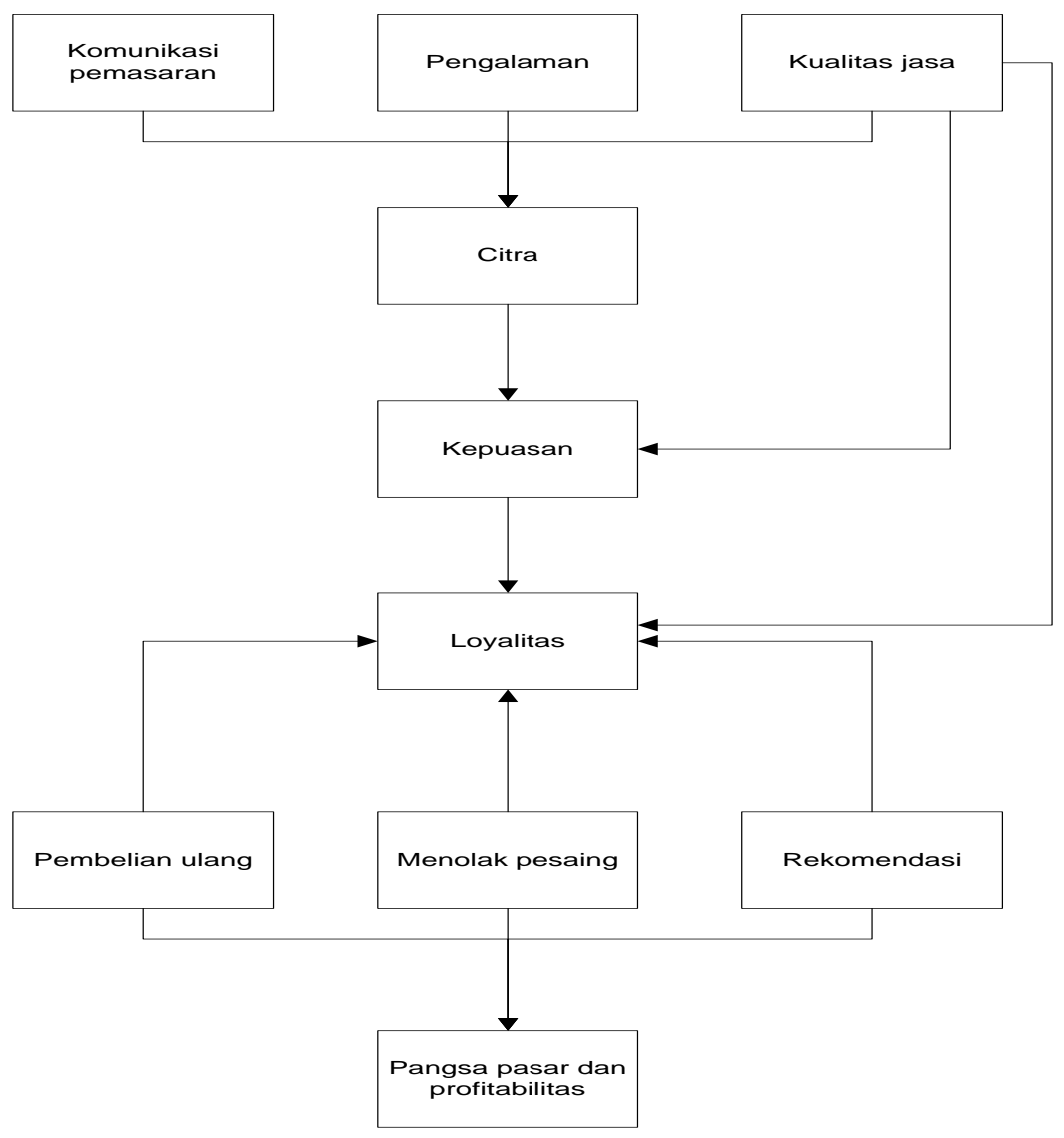

Gambar 1. Kerangka pemikiran

Berdasarkan latar belakang dan identifikasi masalah, tujuan penelitian dan landasan teori dalam kerangka pemikiran, maka dapat diajukan hipotesis dan model penelitian yaitu(1) komunikasi pemasaran berpengaruh terhadap citra tempat rekreasi, (2) pengalaman wisatawan berpengaruh terhadap citra tempat rekreasi, (3) kualitas jasa berpengaruh terhadap citra tempat rekreasi, (4) kualitas jasa berpengaruh terhadap kepuasan, (5) kualitas jasa berpengaruh terhadap loyalitas, (6) citra tempat rekreasi berpengaruh terhadap kepuasan, (7) citra tempat rekreasi berpengaruh terhadap loyalitas, dan (8) kepuasan berpengaruh terhadap loyalitas. Beriku kerangka pemikiran penelitian ini. 
Model penelitian ini memprediksi bahwa loyalitas wisatawan secara langsung dipengaruhi oleh citra tempat rekreasi, kualitas jasa dan kepuasan. Loyalitas wisatawan merupakan intensi perilaku wisatawan seperti intense terhadap pembelian ulang (repurchase), penolakan terhadap pesaing (competitor rejected), dan merekomendasikan (recommended) sebagai indikator jasa yang dipertimbangkan dari loyalitas konsumen. Citra diukur berdasar dimensi holistik dan atribut tempat rekreasi air terjun dari komunikasi pemasaran, pengalaman wisatawan dan kualitas jasa sebagai penyebabnya. Dari kualitas yang dirasakan wisatawan dari tempat rekreasi air terjun sebagai penyebab, bersama-sama dengan citra dan kepuasan dapat membentuk loyalitas wisatawan. Wisatawan dari tempat rekreasi yang melakukan kunjungan berulang tidak memilih tempat rekreasi lain yang sejenis dan mengajak orang lain berkunjung sebagai pengukuran loyalitas wisatawan berakibat pada peningkatan jumlah kunjungan wisatawan nusantara, profit dan peningkatan investasi.

Penelitian ini merupakan penelitian pemasaran jasa pariwisata untuk mendapatkan gambaran sejauhmana komunikasi pemasaran, pengalaman dan kualitas jasa sebagai penyebab terbentuknya citra dan kepuasan serta dampaknya pada loyalitas wisatawan domestik di tempat rekreasi air terjun. Populasi wisatawan yang dipilih sebagai unit pengamatan dan analisis ini adalah wisatawan domestik atau nusantara sebagai pengunjung tempat rekreasi air terjun pada akhir minggu (bukan hari libur nasional) selama periode waktu bulan Mei-Juni 2015. Objek penelitian adalah tempat wisata air terjun di Bogor, yaitu Curug Bidadari dan Curug Nangka. Pendekatan penelitian ini menggunakan pendekatan descriptive dan causal research. Descriptive research adalah penelitian untuk mendapatkan gambaran mengenai fenomena atau hubungan antar fenomena yang diteliti dengan sistematis, faktual dan akurat melalui survey. Fenomena loyalitas wisatawan nusantara sebagai dampak yang berkaitan dengan fenomena citra tempat rekreasi air terjun merupakan variabel dependen yang dipengaruhi variabel independen komunikasi pemasaran, pengalaman, dan kualitas jasa. Sedangkan causal atau verificative research adalah penelitian untuk menguji hipotesis sebagai hubungan antara loyalitas dengan kepuasan, citra, kualitas jasa, pengalaman, dan komunikasi pemasaran.

Sesuai dengan permasalahan yang diidentifikasikan, penelitian ini menggunakan 3 variabel independen (exogenous) dan 3 variabel dependen (endogenous). Variabel laten exogenous adalah variabel bebas/independen yang diperkirakan mempengaruhi variable lain. Dalam penelitian ini ada 3 variabel penyebab yaitu komunikasi pemasaran, pengalaman dan kualitas jasa. Variabel endogenous adalah variabel akibat yang tidak bebas diperkirakan sebagai konsekuensi. Nilainya dipengaruhi oleh variabel lain. Dalam penelitian ini ada 3 variabel akibat yaitu citra, kepuasan dan loyalitas. Masingmasing variabel independen mempunyai indikator yang disusun berdasarkan referensi konsep dan hasil penelitian yang relevan yaitu komunikasi pemasaran dengan 5 pertanyaan yaitu pemasaran yang menarik dan komunikasi pemasaran yang membujuk berasal dari Lumsdon (1997). Pengalaman dengan 10 pertanyaan yaitu pengalaman dalam penilaian kualitas teknikal dan pengalaman dalam penilaian kualitas fungsional berasal dari Schiffman dan Kanuk (2000) dan Witt \& Moutinho (1994). Kualitas jasa dengan penilaian kualitas teknis dan kualitas fungsional, 15 pertanyaan yang merupakan kinerja atribut tangible dan atribut kinerja non produk (intangible) berasal dari Brady dan Taylor (2001) dan Schiffman \& Kanuk (2000). Kepuasan wisatawan diukur dengan menggunakan 3 pertanyaan yaitu penilaian atas kepuasan jasa total, membandingkan dengan pesaing, dan kualitas jasa ideal berasal dari Nguyen \& LeBlanc (1998) dan Andreassen \& Lindestad (1997). Citra tempat rekreasi dengan 8 pertanyaan terdiri dari penilaian kesan terhadap pengelola tempat rekreasi, kontribusi tempat rekreasi dan reputasi tempat rekreasi berasal dari 
Nguyen \& LeBlanc (1998) dan Andreassen \& Lindestad (1997). Sedangkan loyalitas wisatawan dengan 7 pertanyaan merupakan penilaian perilaku dan sikap terhadap kunjungan berulang, menolak pesaing/tidak mengunjungi tempat rekreasi lain, dan memberi rekomendasi tempat rekreasi tersebut kepada orang lain berasal dari Nguyen \& LeBlanc (1998) dan Andreassen \& Lindestad (1997).

Populasi dalam penelitian ini adalah wisatawan nusantara yang datang dan berekreasi di Bogor. Penentuan tempat wisata air terjun ini berdasarkan identifikasi masalah dan data lapangan terutama pada tempat rekreasi air terjun di Bogor, yaitu Curug Bidadari dan Curug Nangka. Dalam penelitian ini dipertimbangkan unit sampel berdasarkan permasalahan serta tujuan penelitian, yaitu wisatawan nusantara yang pernah mengunjungi tempat wisata air terjun yang dipilih. Pengumpulan data dilakukan melalui sampling acak sederhana menggunakan kuesioner berskala likert 1-5. Analisis multivariate yang digunakan adalah Structural Equation Modeling, pertimbangan analisis ini merupakan perluasan dari beberapa teknik multivariate termasuk multiregresi dan analisis faktor yang mampu menjelaskan hubungan variabel tidak bebas secara simultan. Selain itu penelitian ini akan menguji 3 variabel yang diprediksi sebagai variabel dependen dengan teknik multivariate untuk mengkonfirmasi suatu hubungan yang pra-spesifik (Hair et al., 1998).

Berkaitan dengan identifikasi masalah penelitian yang akan mencari hubungan atau pengaruh dari beberapa variable terhadap loyalitas wisatawan, sesuai juga teknik analisis yang digunakan, maka ukuran sampel yang akseptabel adalah 30-100 responden. Jumlah ini merupakan ukuran sampel kritis dalam pengukuran sampel yang diperlukan melalui SEM dengan pendekatan varians (Partial Least Square Path Modeling-PLS PM) (Yamin \& Kurniawan, 2011). Semakin besar jumlah sampel, akan menghasilkan model yang semakin baik.Berdasarkan ukuran sampel tersebut, kemudian disebar kuesioner di kedua tempat rekreasi air terjunCurug Bidadari dan Curug Nangka. Dari masing-masing 75 kuesioner yang disebar pada kedua air terjun tersebut, terkumpul 114 kuesioner lengkap yang dapat diolah.

Metode analisis data yang digunakan yaitu metode analisis deskriptif dan Partial Least Square (PLS). Analisis ini digunakan untuk menggambarkan hasil yang diperoleh dari penyebaran angket sehingga dapat disajikan gambaran faktor-faktor yang dapat mempengaruhi loyalitas responden melalui statistik deskriptif. Statistik deskriptif merupakan alat bantu statistik untuk mendeskripsikan data-data yang dikumpulkan dalam penelitian. Analisis dilakukan dengan mentransformasikan data mentah ke dalam bentuk data yang mudah dimengerti dan ditafsirkan untuk kemudian disusun, dimanipulasi, dan disajikan dalam suatu bentuk informasi.Selain itu data dianalisis dengan menggunakan metode Partial Least Square (PLS) dan menggunakan tools SmartPLS. PLS adalah salah satu metode alternatif SEM (Structural Equation Modeling) yang dapat digunakan untuk mengatasi permasalahan dalam hubungan. Jumlah sampel yang kecil dan penggunaan indikator refleksive membuat PLS lebih sesuai untuk dipilih dibandingkan dengan alat analisis lain. Berikut persamaan inner model.

$$
\eta=\eta \beta+\xi \Gamma+\zeta
$$

Di mana $\eta$ menggambarkan sebuah matriks laten endogen; $\xi$ adalah sebuah matriks laten eksogen; Masing-masing $\beta$ dan $\Gamma$ adalah koefisien matriks dari variabel endogen dan eksogen. $\zeta$ adalah inner model residual matrix. Persamaan outer model

$$
\begin{aligned}
& \mathrm{x}=\Pi_{x} \xi+\varepsilon_{x} \\
& \mathrm{y}=\Pi_{y} \eta+\varepsilon_{y}
\end{aligned}
$$


$x$ dan y adalah matriks variabelmanifest yang berhubungan dengan laten eksogen $\xi$ dan laten endogen $\eta, \Pi_{x}$ dan $\Pi_{y}$ adalah matriks koefisien. $\varepsilon_{x}$ dan $\varepsilon_{y}$ masing-masing adalah matriks outer model residu. Sedangkan evaluasi model dalam PLS meliputi evaluasi outer model atau model pengukuran.

Evaluasi ini meliputi convergent validity dan discriminant validity melalui cross loading dan akar rata-rata variance extracted, serta composite reliability. Evaluasi inner model atau model structural, model struktural dapat dievaluasi melalui $\mathrm{R}^{2}$ (reliabilitas indikator) untuk konstrak dependen dan nilai t-statistik dari pengujian koefisien jalur.Pengujian Hipotesis $(\beta, \gamma$, dan $\lambda)$ dilakukan dengan metode resampling Bootstrap yang dikembangkan oleh Geisser \& Stone. Statistik uji yang digunakan adalah statistik t atau uji t.

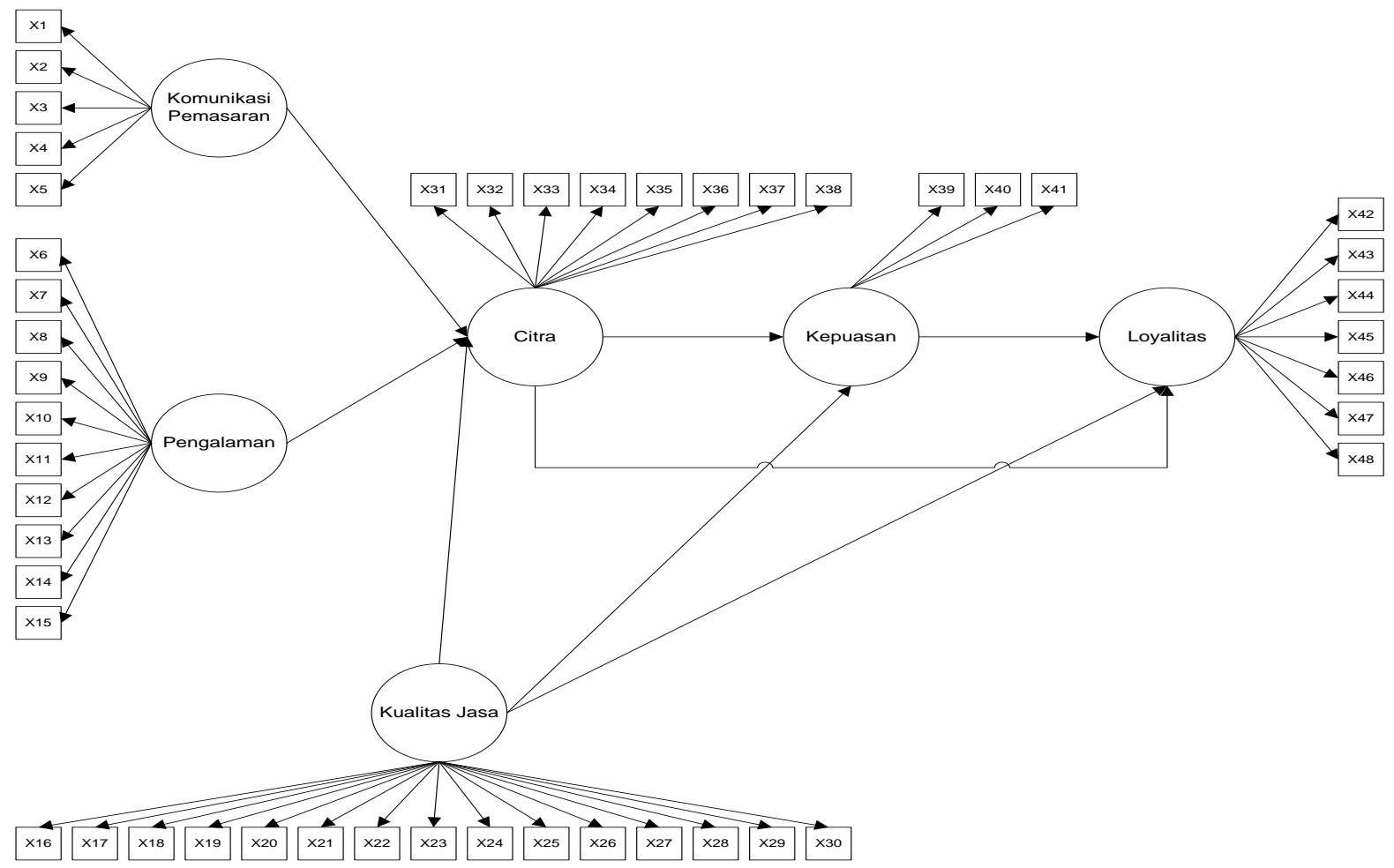

Gambar 2. Model struktural pengaruh kualitas jasa terhadap persepsi nilai, kepuasan dan kepercayaan serta loyalitas

Penerapan metode resampling, memungkinkan berlakunya data terdistribusi bebas (distribution free) tidak memerlukan asumsi distribusi normal, serta tidak memerlukan sampel yang besar (direkomendasikan sampel minimum 30). Pengujian dilakukan dengan $t$-test, bilamana diperoleh $p$-value $\leq 0,05$ (alpha $5 \%$ ) berarti signifikan.

\section{HASIL DAN PEMBAHASAN}

Pada karakteristik responden diuraikan mengenai jenis kelamin, umur, pendidikan, pekerjaan, frekuensi kunjungan, kota asal, sumber informasi, dan kegiatan yang dilakukan di tempat 
wisata Curug Bidadari dan Curug Nangka.Berdasarkan hasil penyebaran kuesioner kepada responden terkumpul 114 kuesioner yang dapat diolah menjadi data penelitian.

\section{Analisis Partial Least Square (PLS)}

Analisis dengan PLS digunakan untuk mengetahui hubungan antara variabel-variabel laten serta variabel laten dengan indikator konstruknya. Dalam penelitian ini, model PLS dibuat berdasarkan data jumlah pengunjung.

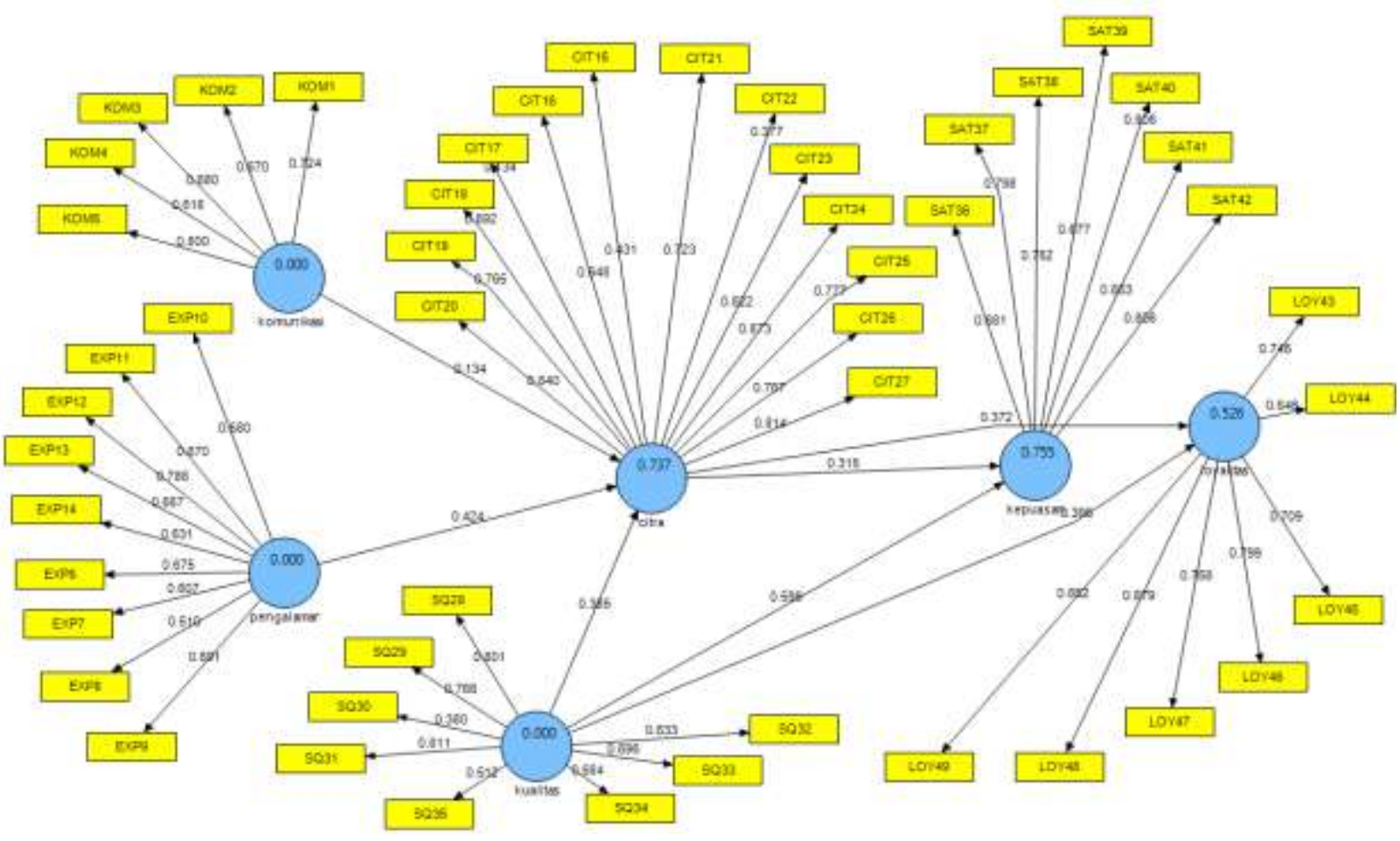

Gambar 3. Model PLS algorithm awal

\section{Evaluasi Measurement Model (Outer Model)}

Convergent validity dari measurement model dengan indikator refleksif dapat dilihat dari korelasi antara score item/indikator dengan score konstruknya. Indikator dianggap reliable jika memiliki nilai korelasi di atas 0,70 , tetapi dapat diterima bila skala loading berada diantara $0,50-0,60$ (Ghozali, 2008).

Pada penelitian ini, nilai loading ditetapkan sebesar 0,6. Sehingga diketahui terdapat beberapa indikator yang bernilai kurang dari 0,6 yaitu penggunaan fasilitas rekreasi dengan peralatan modern (atm, telepon) di tempat rekreasi ini, pengaruh tempat rekreasi ini bagi daerah sekitarnya, lingkungan alam di tempat rekreasi ini terasa nyaman,lalulintas ke lokasi tempat rekreasi mudah dicapai, parkir kendaraan terjamin aman, tempat berenang atau berendam nyaman, penataan taman di arena rekreasi, keadaan toilet yang tersedia di tempat rekreasi, dan informasi disertai gambar dari fasilitas rekreasi yang disediakan. Beberapa indikator tersebut di drop sehingga menghasilkan seperti pada Gambar 4. 


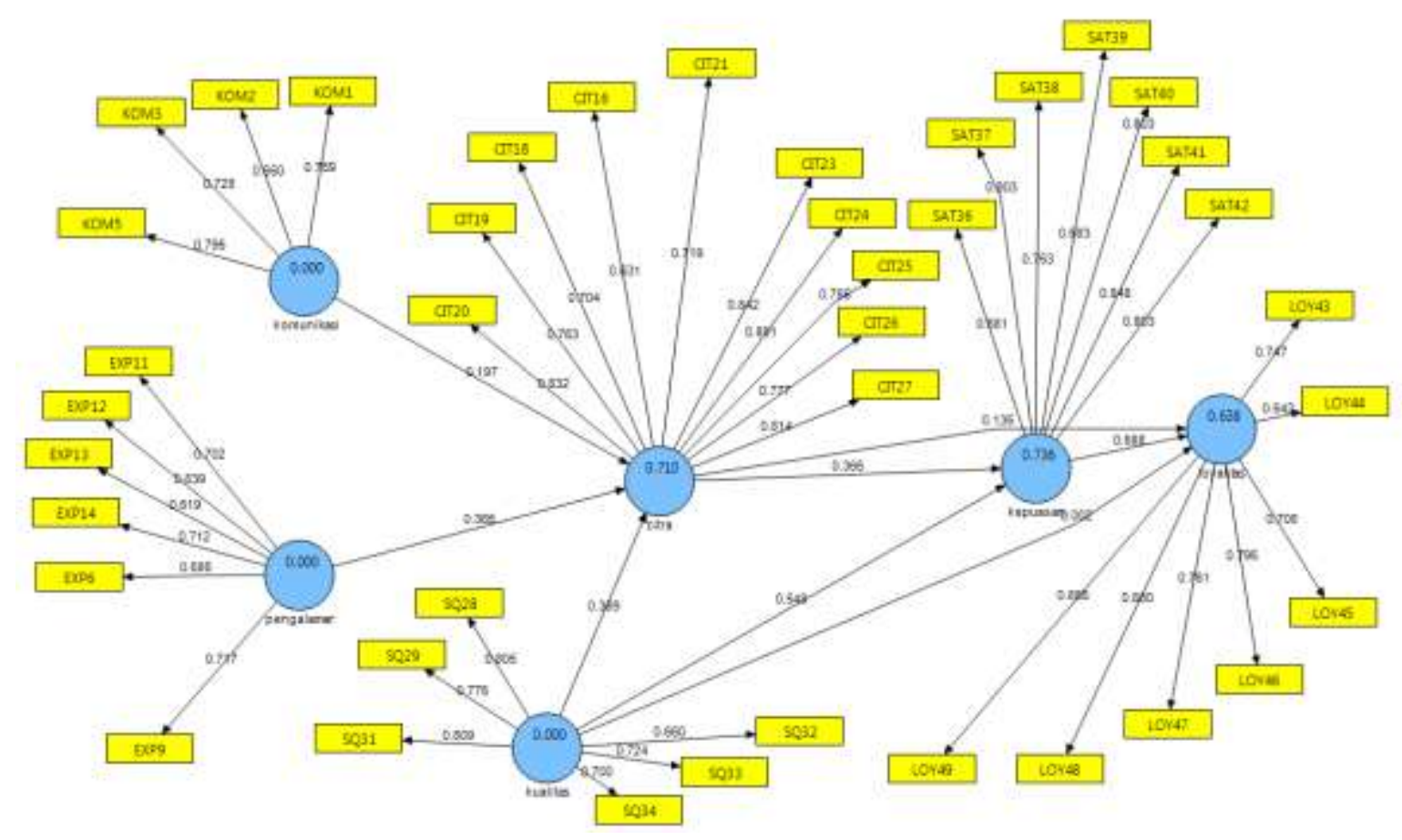

Gambar 4. Model PLS algorithm setelah pendropan

Discriminant Validity indikator refleksif dapat dilihat pada cross loading antara indikator dengan konstruknya berikut ini output SmartPLS. Discriminant validity digunakan untuk memastikan bahwa setiap konsep dari variabel laten/konstruk berbeda dengan variabel laten lainnya. Model mempunyai discriminant validity yang baik jika setiap nilai loading dari setiap indikator setiap variabel latent memiliki nilai loading yang paling besar dengan nilai loading lain terhadap variabel latennya. Sehingga dapat disimpulkan bahwa indikator pada konstruk kepuasan, komunikasi pemasaran, kualitas jasa, loyalitas dan pengalaman memiliki tingkat discriminant validity yang baik. Hal ini menunjukkan bahwa indikator tersebut memiliki validitas yang baik. Uji lain untuk menilai validitas dari konstruk dengan melihat nilai AVE. Model yang baik bila AVE masing-masing konstruk nilainya lebih besar dari 0,50. Nilai untuk citra sebesar 0,607267, kepuasan sebesar 0,592892, komunikasi sebesar 0,539808 , kualitas sebesar 0,558698 , loyalitas sebesar 0,597985 , dan pengalaman sebesar 0,512148 .

Disamping uji validitas konstruk, dilakukan uji reliabilitas konstruk yang diukur dengan2 kriteria, yaitu composite reliability dan cronbach alpha dari blok indikator yang mengukur konstruk. Konstruk dinyatakan reliable jika nilai composite reliability maupun cronbach alpha di atas 0,70 . Nilai untuk citra sebesar 0,938764, kepuasan sebesar 0,910178, komunikasi sebesar 0,823547, kualitas sebesar 0,883111 , loyalitas sebesar 0,911585 , dan pengalaman sebesar 0,862001 . Sedangkan nilai cronbach alpha untuk citra sebesar 0,926719 , kepuasan sebesar 0,884070 , komunikasi sebesar 0,713204 , kualitas sebesar 0,841012 , loyalitas sebesar 0,887569 , dan pengalaman sebesar 0,807572 . 


\section{Pengujian Model Struktural (Inner Model)}

Pengujian terhadap model struktural dilakukan dengan melihat nilai R-square yang merupakan uji goodness of fit model. Model pengaruh komunikasi pemasaran, pengalaman, citra, kualitas jasa, kepuasan dan loyalitas memberikan nilai $R$-square. Nilai $R^{2}$ citra sebesar 0,709924 dapat diinterpretasikan bahwa variabilitas konstruk citra dapat dijelaskan oleh variabilitas konstruk komunikasi pemasaran, pengalaman dan kualitas jasa sebesar 70,9924\% sedangkan 29,0076\% dijelaskan variabel lain diluar penelitian. Begitupun dengan nilai $R^{2}$ kepuasan sebesar 0,737476 berarti variabilitas kepuasan dapat dijelaskan oleh variabilitas citra dan kualitas jasa sebesar $73,7476 \%$ sedangkan sisanya dijelaskan variabel lain. Dan terakhir, $R^{2}$ loyalitas bernilai 0,513794 menunjukkan bahwa variabilitas citra, kepuasan dan kualitas jasa menjelaskan variabilitas loyalitas sebesar $51,3794 \%$ dengan lainnya dijelaskan oleh variabel diluar penelitian. Signifikansi konstruk penelitian dapat dilihat melalui nilai koefisien parameter dan nilai signifikansi t-statistik berikut.

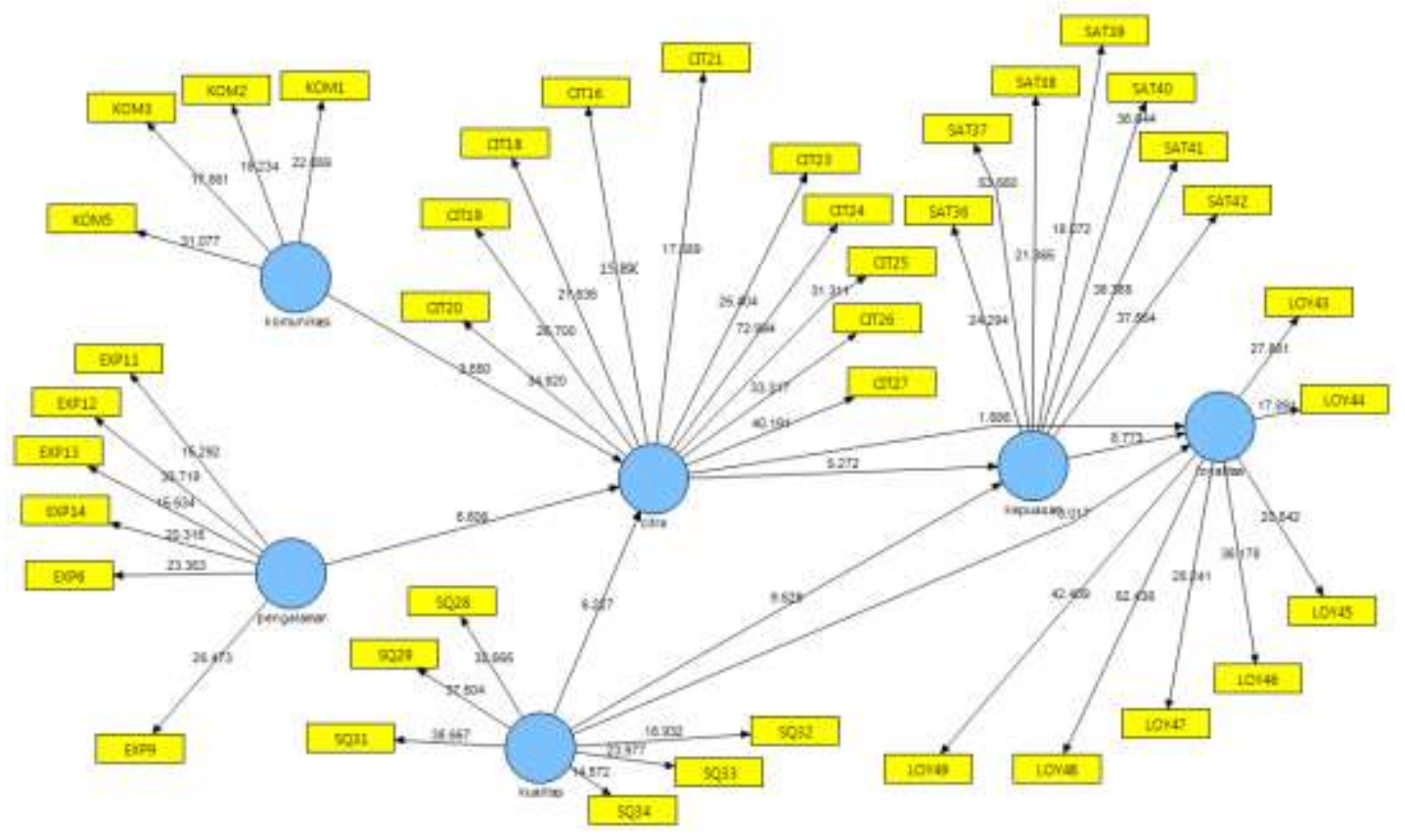

Gambar 5. Model bootstrapping

Berdasarkan Path Coefficients dapat disimpulkan beberapa hal, yaitu hubungan antara komunikasi pemasaran dengan citra. Berdasarkan Tabel 5, nilai t-statistik hubungan komunikasi pemasaran denga citra sebesar 3.550, nilai ini lebih besar dari nilai t-tabel 1,96 untuk level signifikan $5 \%$. Karena itu dapat dinyatakan bahwa hipotesis $1(\mathrm{H} 1)$ diterima yang menyatakan bahwa komunikasi pemasaran berhubungan signifikan terhadap citra. Hasil penelitian ini sesuai dengan penelitian serupa yang dilakukan Echtner dan Ritchie (1991) dan Priyatiningsih (2005) dimana komunikasi yang menarik akan membentuk citra yang positif dan mendorong wisatawan berkunjung.

Sedangkan hubungan antara pengalaman dengan citra terlihat bahwa dibandingkan dengan komunikasi pemasaran, pengalaman lebih berperan dalam membentuk citra tempat rekreasi (loading $0,365>0,197$ ) dengan t-statistik sebesar 6,606 (lebih besar dari t-tabel 1,96). Hal ini sesuai dengan pernyataan Kurtz dan Clow (1998) dan menjawab hipotesis 2 dimana pengalaman berpengaruh 
signifikan terhadap citra rekreasi. Jadi benar bahwa tempat rekreasi air terjun bagi konsumen merupakan pengalaman dari diri sendiri atau orang lain melalui jasa wisata yang tangible.

Hubungan antara kualitas jasa dengan citra, nilai t-statistik hubungan kualitas jasa dengan citra sebesar 6,227, nilai ini lebih besar dari nilai t-tabel 1,96. Karena itu dapat dinyatakan bahwa hipotesis ketiga $(\mathrm{H} 3)$ diterima yang menyatakan bahwa kualitas jasa berhubungan signifikan terhadap citra. Kualitas jasa berpengaruh paling dominan terhadap citra dibandingkan pengalaman dan komunikasi (loading 0,389 > 0,365 > 0,197). Lewis dan Chambers (2000) menyatakan pengalaman dalam produk hospitality adalah kesan personal yang intangible. Kualitas jasa fungsional yang holistik ini pengukurannya cukup sulit karena tergantung pada persepsi individu (Witt dan Moutinho, 1989).

Hubungan antara kualitas jasa dengan kepuasan, nilai t-statistik hubungan kualitas jasa terhadap kepuasan sebesar 9.629, nilai ini lebih besar dari nilai t-tabel 1,96 untuk level signifikan $5 \%$. Karena itu dapat dinyatakan bahwa hipotesis keempat $(\mathrm{H} 4)$ diterima yang menyatakan bahwa kualitas jasa berhubungan signifikan terhadap kepuasan. Hasil ini sejalan dengan penelitian Riduan et al. (2015) terhadap persepsi turis mancanegara terhadap pemasaran wisata di Indonesia.

Hubungan antara kualitas jasa dengan loyalitas, nilai t-statistik hubungan kualitas jasa terhadap loyalitas sebesar 0.017 , nilai ini lebih kecil dari nilai t-tabel 1,96 untuk level signifikan 5\%. Karena itu dapat dinyatakan bahwa hipotesis kelima (H5) ditolak yang menyatakan bahwa kualitas jasa berhubungan signifikan terhadap loyalitas. Dari hasil penelitian ini teruji bahwa kualitas jasa yang diukur dari kinerja pengelola jasa melalui technical quality dan functional quality mempunyai pengaruh lemah sehingga tidak signifikan terhadap loyalitas. Hasil ini serupa dengan penelitian yang dilakukan Nguyen dan LeBlanc (1998) terhadap nasabah bank yang kembali menjadi member dari credit union bukan karena kualitas spesifik transaksi tetapi lebih dikarenakan citra bank. Indikator yang kuat dari loyalitas berasal dari rekomendasi dengan positif word of mouth, sedangkan untuk repeat purchase dan tetap memilih tempat rekreasi dengan menolak pesaing, juga sebagai indikator loyalitas meskipun tidak sekuat rekomendasi.

Hubungan antara citra dengan kepuasan, nilai t-statistik hubungan citra terhadap kepuasan sebesar 5.272, nilai ini lebih besar dari nilai t-tabel 1,96 untuk level signifikan 5\%. Karena itu dapat dinyatakan bahwa hipotesis keenam $(\mathrm{H} 6)$ diterima yang menyatakan bahwa citra berhubungan signifikan terhadap kepuasan. Hasil penelitian ini mendukung penelitian Riduan et al. (2015) dimana citra destinasi tempat wisata mempengaruhi kepuasan wisatawan mancanegara di Indonesia.

Hubungan antara citra dengan loyalitas, nilai t-statistik hubungan citra terhadap loyalitas sebesar 1.686, nilai ini lebih kecil dari nilai t-tabel 1,96 untuk level signifikan $5 \%$. Karena itu dapat dinyatakan bahwa hipotesis keempat $(\mathrm{H} 7)$ ditolak yang menyatakan bahwa citra berhubungan signifikan terhadap loyalitas. Hipotesis ini bertentangan dengan pendapat Heung et al. (1996) dalam penelitian terhadap tiga pasar wisata tentang loyalitas hotel yang dipengaruhi citra, serta hasil penelitian Kandampully dan Suhartanto (2000) yang menyatakan kecenderungan konsumen untuk melakukan pembelian ulang dan memberi rekomendasi dengan citra yang menyenangkan sehingga dipercaya memberi jaminan kualitas jasa yang tinggi (Kandampully dan Suhartanto, 2000). Walaupun secara langsung citra tidak berpengaruh terhadap loyalitas, tetapi citra berpengaruh tidak langsung terhadap loyalitas melalui kepuasan. Artinya, citra positif baru dapat dirasakan konsumen setelah merasakan kepuasan terlebih dahulu yang pada akhirnya akan membentuk loyalitas.

Hubungan antara kepuasan dengan loyalitas, nilai t-statistik hubungan kepuasan terhadap loyalitas sebesar 8.773 , nilai ini lebih besar dari nilai t-tabel 1,96 untuk level signifikan $5 \%$. Karena itu dapat dinyatakan bahwa hipotesis keempat $(\mathrm{H} 8)$ diterima yang menyatakan bahwa kepuasan 
berhubungan signifikan terhadap loyalitas. Penelitian Riduan et al. (2015) memberikan hasil yang sama dimana kepuasan turis mancanegara di Indonesia akan berpengaruh terhadap loyalitas. Selain interelasi antar konstruk, berikut ini dijelaskan indikator-indikator yang paling dominan membentuk konstruk-konstruk terlihat pada tabel berikut.

Pada konstruk komunikasi pemasaran, indikator yang paling dominan yaitu brosur tentang tempat rekreasi ini dibandingkan brosur tempat rekreasi lain, kemudian diikuti oleh fasilitas rekreasi yang diinformasikan oleh pengelola, iklan yang mengajak untuk berkunjung ke tempat rekreasi ini. Sedangkan indikator terendah adalah kesan orang tentang tempat rekreasi ini dibandingkan tempat rekreasi lain. Selanjutnya pada kostruk pengalaman, indikator paling dominan adalah pelayanan wisata secara keseluruhan di tempat rekreasi ini, diikuti dengan kondisi restoran yang ada di sekitar tempat rekreasi ini, penetapan tarif atas pelayanan yang diterima, pelayanan petugas dalam membantu pengunjung, kondisi lingkungan alam di tempat rekreasi ini. Sedangkan indikator terendah adalah rekreasi di tempat ini sebagai tempat rekreasi alami. Pada konstruk citra, indikator paling dominan adalah petugas yang ada bersikap ramah melayani pengunjung, diikuti dengan petugas yang ada terampil melayani pengunjung, fasilitas rekreasi yang tersedia sesuai dengan yang dipromosikan, pelayanan yang diterima pengunjung sesuai dengan permintaan, petugas yang ada melayani pengunjung dengan sopan, petugas yang ada mudah dihubungi untuk memberikan pelayanan, informasi wisata (petunjuk arah/denah) di lokasi tempat rekreasi jelas, keamanan barang bawaan pengunjung terjamin, dan petugas yang ada memberi pelayanan kepada pengunjung dengan cepat. Sedangkan indikator terendah adalah kondisi tempat berendam terjaga kebersihannya.Sedangkan pada konstruk kualitas jasa, indikator yang paling dominan adalah fasilitas rekreasi yang disediakan, diikuti dengan pengelolaan tempat rekreasi ini sebagai tempat rekreasi, penyediaan lahan pedagang kaki lima oleh pengelola tempat rekreasi, reputasi tempat rekreasi ini sebagai tempat rekreasi, kenyamanan berekreasi di tempat rekreasi ini. Indikator terendah adalah petugas yang melayani pengunjung. Dari konstruk kepuasan terlihat bahwa indikator yang paling dominan adalah promosi yang dilakukan tempat rekreasi ini sebagai suatu tempat rekreasi, kemudian diikuti dengan berekreasi di tempat rekreasi ini disbanding berekreasi di tempat lain, pelayanan petugas tempat rekreasi ini sebagai suatu tempat rekreasi, penampilan tempat rekreasi ini sebagai tempat rekreasi yang terkenal, penetapan harga tanda masuk ke tempat rekreasi ini disbanding tempat rekreasi lain, fasilitas rekreasi tempat rekreasi ini sebagai suatu tempat rekreasi alam. Indikator terendah adalah manfaat yang dirasakan dengan berekreasi di tempat rekreasi ini secara keseluruhan.Dari aspek loyalitas, indikator yang paling dominan adalah responden memberiktahukan manfaat rekreasi di tempat rekreasi ini kepada orang lain, diikuti dengan menyarankan orang lain untuk berekreasi ke tempat rekreasi ini, melakukan kunjungan secara rutin ke tempat rekreasi ini, lebih memilih tempat rekreasi ini sebagai tempat rekreasi berwisata alam disbanding tempat rekreasi lain, berkunjung kembali ke tempat rekreasi ini, memilih tempat rekreasi ini sebagai tempat rekreasi di akhir minggu. Sedangkan indikator terendah adalah bercerita kepada orang lain tentang kesan menyenangkan berlibur di tempat rekreasi ini.

Pengujian terhadap inner model dilakukan dengan melihat nilai $R-S q u a r e$ yang merupakan uji goodness of fit model. Nilai $R-S q u a r e ~ u n t u k$ variabel laten citra didapatkan nilai sebesar 0,7099, hal ini menunjukkan bahwa variabel laten komunikasi pemasaran, pengalaman dan kualitas jasa berhubungan sebesar 70,99\% terhadap citra. Sedangkan sisanya dijelaskan oleh variabel lain yang tidak termasuk dalam penelitian ini. Selanjutnya nilai $R$-Square variabel laten kepuasan adalah sebesar 0,7364, hal ini mengindikasikan bahwa citra dan kualitas jasa berhubungan sebesar 73,64\% dengan kepuasan. Sedangkan sisanya dijelaskan oleh variabel lain yang tidak termasuk dalam 
penelitian ini. Dan terakhir nilai $R$-Square variabel laten loyalitas sebesar 0,6382 , hal ini menunjukkan bahwa citra, kepuasan dan kualitas jasa berhubungan sebesar $63,82 \%$ dengan loyalitas. Sedangkan sisanya dijelaskan oleh variabel lain diluar penelitian ini.

\section{PENUTUP}

Berdasarkan hasil penelitian yang dilakukan, maka dapat ditarik beberapa kesimpulan yaitu komunikasi pemasaran berhubungan signifikan terhadap citra. Hal ini menunjukkan bahwa komunikasi yang menarik akan membentuk citra yang positif dan mendorong wisatawan berkunjung. Dibandingkan dengan komunikasi pemasaran, pengalaman lebih berperan dalam membentuk citra tempat rekreasi. Bahwa tempat rekreasi air terjun bagi konsumen merupakan pengalaman dari diri sendiri atau orang lain melalui jasa wisata yang tangible.Kualitas jasa berhubungan signifikan terhadap citra. Kualitas jasa berpengaruh paling dominan terhadap citra dibandingkan pengalaman dan komunikasi. Kualitas jasa berhubungan signifikan terhadap kepuasan. Kualitas jasa tidak berhubungan signifikan terhadap loyalitas. Dari hasil penelitian ini teruji bahwa kualitas jasa yang diukur dari kinerja pengelola jasa melalui technical quality dan functional quality mempunyai pengaruh lemah sehingga tidak signifikan terhadap loyalitas. Citra berhubungan signifikan terhadap kepuasan. Citra tidak berhubungan signifikan terhadap loyalitas. Walaupun secara langsung citra tidak berpengaruh terhadap loyalitas, tetapi citra berpengaruh tidak langsung terhadap loyalitas melalui kepuasan. Artinya, citra positif baru dapat dirasakan konsumen setelah merasakan kepuasan terlebih dahulu yang pada akhirnya akan membentuk loyalitas. Kepuasan berhubungan signifikan terhadap loyalitas. Dari semua variabel yang memiliki pengaruh terhadap loyalitas, pengaruh terbesar adalah variabel kepuasan responden, yaitu promosi yang dilakukan tempat rekreasi ini sebagai suatu tempat rekreasi.

Ada beberapa saran dapat diberikan berdasarkan penelitian yang dilakukan, yaitupihak pengelola perlu memperhatikan faktor-faktor yang membentuk kualitas jasa, seperti fasilitas rekreasi yang disediakan, pengelolaan tempat rekreasi, penyediaan lahan pedagang kaki lima oleh pengelola, reputasi tempat rekreasi, kenyamanan tempat rekreasi dan petugas yang melayani pengunjung. Selain itu, pengelola juga perlu memperhatikan faktor-faktor yang membentuk citra, seperti petugas bersikap ramah dan terampil dalam melayani pengunjung, fasilitas rekreasi yang tersedia sesuai dengan yang dipromosikan, pelayanan yang diterima pengunjung sesuai dengan permintaan, petugas yang ada melayani pengunjung dengan sopan, petugas yang ada mudah dihubungi untuk memberikan pelayanan, informasi wisata (petunjuk arah/denah) di lokasi tempat rekreasi jelas, keamanan barang bawaan pengunjung terjamin, dan petugas yang ada memberi pelayanan kepada pengunjung dengan cepat, dan kondisi tempat berendam terjaga kebersihannya. Penelitian ini hanya dibatasi pada Curug Bidadari dan Curug Nangka, sedangkan di Bogor masih banyak terdapat curugcurug lainnya. Oleh karena itu perlu adanya penelitian lanjutan yang terkait dengan penelitian ini dan melibatkan jumlah responden yang lebih besar.

\section{REFERENSI}

Andreassen, T.W., \& Lindestad, B. (1997). Customer loyalty and complex services-The impact of corporate image and loyalty for customer with varying degrees of service expertise. International journal of service industry management, vol. 9(1), MCB University Press.

Brady, M.K., \& Cronin Jr., J.J. (2001). Some new thought on conceptualizing perceived service quality: A hierarchical approach. Journal of marketing, vol. 65. 
Echtner, C.M., \& Ritchie Jr., B. (1991). The meaning and measurement of destination image. The Journal of tourism studies, vol 2(2).

Ghozali, I(2008). Structural equation modeling alternatif dengan Partial Least Square PLS. Semarang: Badan Penerbit UNDIP.

Hair, J.F. Jr. , Anderson, R.E., Tatham, R.L., \& Black, W.C. (1998). Multivariate data analysis. (5 $5^{\text {th }}$ Edition). Upper Saddle River, NJ: Prentice Hall.

Kotler, P. (2002). Manajemen pemasaran-Edisi milenium. Jakarta: Prehalindo.

Kurtz, D.L., \& Clow, K.E. (1998). Service marketing. USA: John Wiley \& Sons.

Lewis, R., \& Chambers, R. (2000). Marketing leadership in hospitality: Foundations and practices. New York: John Wiley \& Sons.).

Loudon, D., \& Della Bitta, A.J. (1988). Consumer behavior. Concepts an applications. Third edition. McGraw-Hill Book Co. Singapore.

Lumsdon, L., (1997). Tourism marketing, London: International thomson business press.

Mill, R., \& Morrison. (1985). The tourism system. USA: Prentice Hall International.

Morison, A. (1996). Hospitality and travel marketing. $2^{\text {nd }}$ edition. USA: Delmar Publishers.

Nguyen, N., \& LeBlanc, G. (1998). The mediating role of corporate image on customers' retention decisions: An investigation in financial services. International journal of bank marketing, vol. 16(2), pp. 52-65.

Nursastri, S.A. (2014). Ini Dia 7 Masalah Utama Pariwisata di Indonesia. detikTravel. Diakses dari http://travel.detik.com/read/2014/02/26/152056/2509137/1382/ini-dia-7-masalah-utamapariwisata-di-indonesia.

Priyatiningsih, K. (2005). Pengaruh komunikasi pemasaran, pengalaman dan kualitas jasa terhadap citra serta dampaknya pada loyalitas wisatawan nusantara (survei tempat rekreasi-air panas di Jawa Barat). Tesis tidak dipublikasikan.Program Pascasarjana Universitas Padjadjaran.

Shiffman, L.G., \& Kanuk, L.L. (2000). Consumer behavior. $6^{\text {th }}$ edition. USA: Prentice Hall International.

Wahab, S., Crampon, L.J., \&Rothfield, L.M. (1997). Pemasaran pariwisata. Jakarta: Pradnya Paramita.

Witt, S., \& Moutinho, L. (1994). Tourism marketing and management handbook. $2^{\text {nd }}$ edition. UK: Prentice Hall International.

Yamin, S., \& Kurniawan, HH (2011). Generasi baru mengolah data penelitian dengan partial least squarepath modelling. Jakarta: Salembainfotek.

Yoeti, O.A. (1996). Pengantar ilmu pariwisata. Bandung: Penerbit Angkasa. 